\title{
PEDAGOGICAL INTERACTION AS A SUBJECT \\ OF SCIENTIFIC REFLECTION OF S. BALAY
}

https://doi.org/10.37096/SHDISJ-19-1.1-0009

\author{
Yatyshchuk Anastasia \\ https://orcid.org/0000-0003-2764-1708 \\ Yablonska Tetiana \\ https://orcid.org/0000-0001-7272-9691
}

The article is devoted to the analysis of pedagogical interaction as one of the leading problems in the theoretical heritage of the prominent Ukrainian-Polish scientist Stepan Balay.

It is shown that Stepan Balay's pedagogical psychology is an integral system of views, which studies the patterns of pedagogical interaction and formation of the child's personality for the purposeful implementation of the pedagogical process, taking into account its age and individual characteristics, peculiarities of human psychic activity in the process of development and self-development. The systematic vector of the educational psychology of S. Balay is its humanistic orientation on the upbringing of the child's personality.

The significant importance of S. Balay's creativity for the development of psychological science is determined by the justification of the consistent concept of the psychology of education, which is marked by a systematic vision of the process of development of the child, understanding of the pedagogical process as a subject-subject interaction, proclaiming love for the child as the basis of education.

The originality of the scientist's views on solving the problems of psychology of education and upbringing is substantiated. The significance of the ideas of the psychology of education of S. Balay for the development of the theory and practice of pedagogical psychology, their role in the context of the tasks of modern education was described.

Key words: Stepan Balay, educational psychology, pedagogical psychology, pedagogical interaction, upbringing.

\section{Introduction}

The domestic system of education remains in the process of reforming and seeking values, on the basis of which educational goals could be defined and appropriate strategies for its development developed. This determines the relevance of studying the historical experience of the formation of an educational ideal, which will promote the search for new approaches to the theory and practice of modern education.

The name of the well-known philosopher, psychologist and teacher Stepan Balay (18851952), whose scientific and pedagogical activity was highly appreciated and recognized in Poland, proved to be undeservedly forgotten in Ukraine. An outstanding psychologist, physician, psychoanalyst and philosopher, S. Balay, with his numerous articles and fundamental works laid the foundations of the educational psychology, personology, developed the doctrine of psychoanalysis, and enriched the ideas of S. Freud, the "deep" psychology of A. Adler and the teachings of K. Jung. He created a solid for his time a scientific theory of personality, which has not lost its value in our day. At the same time, despite the great theoretical, methodological and practical significance of the ideas of S. Balay, world recognition of him as one of the founders of pedagogical psychology, the scientific heritage of the scientist has not been sufficiently investigated in domestic psychological science. The ideas of the scientist regarding the humanistic essence and peculiarities of pedagogical interaction are especially important in the context of the improvement of the domestic educational system.

The purpose of the article - to analyze the views of S. Balay on the essence of pedagogical interaction as one of the central problems of educational psychology.

\section{Methodology}

The analysis of researches and publications devoted to the scientific work of S. Balay shows that the name of the scientist is little known to the general public of domestic psychologists, since the study of his scientific heritage began in Ukraine relatively recently. Until the 1960's. his name was 
mentioned only occasionally, mainly in the critical context that was caused by ideological reasons. According to O. Goncharenko, the creative work of the scientist, whose outlook was formed largely under the influence of world humanistic ideological trends of the second half of the nineteenth and the early twentieth centuries, could not be recognized as a domestic psychological science, since most of S. Balay's ideas contradicted the provisions of the Soviet psychological school, which for a long time was dominant in the system of education and science (Goncharenko, 2011).

The study of the creative work of S. Balay in Ukraine is primarily due to the scientific and educational activities of Professor M. Vernikov, who systematized the works of the scientist and actively popularized his ideas among the scientific and educational community. In recent years, research on various problems of S. Balay's creativity has intensified in Ukraine (Rybalka, 2009; Vasyanovich, 2005; Vernikov, 2002; Yatyshchuk, 2012, etc.).

The works of the scientist are highly respected by modern Polish scholars and his textbooks are still used in higher educational institutions of Poland (Encyklopedia Powszechna, 1983).

The great importance of the scientific work of S. Balay for the Polish psychological science is emphasized by researchers of the middle of the twentieth century, as well as by modern scholars (Jadczak, 1997; Kosnarewicz, 1992; Żebrowska, 1952; Ziemnowicz, 1953, etc.). The world scientific society was also revealed interest in S.Balay's works, in particular, the contribution of the scientist to psychodydactics, the development of the psychology of education was noted (Craighead, 2002).

The basis of the research were the principles of objectivity, scholarship and historicism, the fundamental provisions of the methodology of the history of psychology - personalized, systemicstructural and context-based approaches (Petrovskiy, 1973; Roments, 1998; Yaroshevsky, 1996).

For solving the task following methods are used: historical and genetic, historical-functional, comparative-historical, biographical and method of systematization of scientific ideas of the scientist.

\section{Results}

The formation of S. Balay as the scientist occurred in a rather complicated period of formation of psychology as a separate branch of scientific knowledge, which was characterized by the existence of contradictory ideas and approaches.

At the turn of the nineteenth and twentieth centuries in Europe, two directions of psychology - the physiological by Vundt and the narrative by Brentano which were functioned simultaneously; the very scientific discussion between them further defined the ways of formation of the basic European psychological concepts.

S. Balay received higher education at Lviv University, where his teacher was K. Tvardovsky, a follower of Brentano, who became one of the founders of psychology in Poland in its humanistic version. The essence of his approach was the recognition of the identity and peculiarity of psychology, a change in the interpretation of its subject (Twardowski, 1997), which led to a certain «methodological fracture» in psychology - a significant decrease in interest about the nature of the soul in favor of finding answers to questions about the properties and functions of the soul, that is mental life.

The worldview of S. Balay was formed under the influence of the ideas of the humanist philosophical trends of the twentieth century

The worldview of S. Balay was formed by the ideas of the humanistic philosophy trends of the philosophy of the twentieth century. In justifying his ideas, the scientist relied on the views of phenomenologists (E. Husserl, V. Dilthey, E. Spranger), psychoanalysts (Z. Freud, A. Adler), gestalt psychologists (V. Kyler), behaviorists (E. Thorndike), humanistic psychologists (S. Buhler) and teachers (E. Weber, R. Lochner). The theoretical concept of S. Balay was formed as an organic synthesis of philosophy, psychology and pedagogy. The basis of the philosophical and methodological concept of S. Balay were ideas: about the immanent-natural nature of the process of formation of the human psyche, which in its formation passes certain regular stages; about a certain autonomy of the psyche and at the same time the unity and interconnection of mental changes with somatic ones. The main vector of this system of views was the humanist orientation on the education of the child's personality, taking into account his individual abilities. According to M.Vernikov the theoretical concept of S. Balay was formed as an organic synthesis of philosophy, psychology and pedagogy; at the same time, 
philosophy is a main source and is noticeably dominant in the views of the scientist, and psychology and pedagogy are so mutually intertwined that in fact constitute inseparable unity (Vernikov, 2002).

According to S. Balay, the need to distinguish the educational psychology is determined by the breadth of educational phenomena, in which manifestations of psychic phenomena, and the need for their psychological analysis. In his essay "Essay on Educational Psychology" (1938), the scientist formulated his understanding of this branch of science: «A psychologist may set himself the task of studying in detail the role played by psychic phenomena in educational activities, and studying the laws that are being implemented in these cases. Since the courses of educational phenomena are very broad, it is not surprising that the attempt to accomplish this task leads to the creation of a special branch of psychology. Therefore, the task of the educational psychology is a psychological analysis of the phenomena of education (and, consequently, upbringing and formation). In this sense, one can define ... pedagogical psychology as a psychology of upbringing» (Baley, 1938: 4).

As S. Balay argued, the psychology of education is a separate science possessing its theoretical and practical levels and can not be identified with the child's psychology or developmental psychology. «Not a child himself, but educational processes are an essential subject of pedagogical psychology, in which it is obvious that when talking about educational processes, one must also speak of the pupil and the educator as the subjects of those processes, however, in that only the moments in which the educational process touches them» (Baley, 1938: 11). At the same time, the psychology of education, according to S. Balay, is closely connected with other sciences: experimental and general psychology, sociology of education, social psychology, psychotherapy, and so on. S. Balay distinguished pedagogical psychology («educational psychology») as a scientific branch of psychology with its subject, purpose, tasks, methods of scientific research, which brought it closer to innovators in the field of psychology.

The key to the scientific work of S. Balay was the idea of humanization of society through the education of man.
Pedagogical interaction is an important object of psychological and pedagogical research in the writings of the scientist, specifying in the justification of the principles of this interaction, methodological tools, requirements for the teacher's personality and his competencies. The scientist substantiated the basic principles on which the pedagogical interaction should be based: humanism, natural development of the child, taking into account its age and individual characteristics in the process of education, subjectivity in education, visibility, and the combination of education with life. S. Balay consistently advocated and promoted these principles, on which the theorists of science and ordinary teachers had to resist.

The field of psychological study of pedagogical interaction for S. Balay was inexhaustible. The teacher's own practice gave him the opportunity to draw up a coherent picture of the child's upbringing process. In considering this question, he analyzes a large number of scientific sources, the most important among them to form his own scientific conception of the upbringing of the works of M. Werering, M. Montessori, A Herzberg, E. Spranger, G. Kershenstein, E. Duhring, G. Hoffmann and others. Like most European educators and psychologists, S. Balay considered the educational process as a systemic integrity. In his writings, he noted that often in psychological discourse attention is drawn only to the process of teaching and learning, but the actual education itself is neglected.

S. Balay interprets the concept of «education» in the broad sense, and the upbringing and study are regarded as its types, which form a synthetic unity in preparing a person for independent life. The essence of the training is to acquire knowledge of the person through which it realistically determines its place in the society and the society's attitude towards it. The purpose of education is to prepare the child for independent life in the community. The scientist did not differentiate between these processes, insisting that the teacher performs first of all an educational function, therefore in his writings he deliberately calls the teacher a tutor.

In the pedagogical process education acts as the transfer of beliefs, thoughts, skills, the whole way of life, and education - as an organized selfdevelopment of the child in the process of learning. At the same time S. Balay pointed out that 
«education should mean the psyche of the child, considered in accordance with the phase of her personal development, taking into account her physical and spiritual needs, her interests and abilities, and not in the average form, but in her individual manifestation characterizing the personality as unique» (Balay, 1995: 17).

According to the scientist, the penetration into the specifics of children's nature, the empirical knowledge of the laws of the child's development and his individual abilities is a condition for more effective pedagogical interaction of the education, due to the creation of a medium in which the child can develop in full measure. S. Balay carried out a thorough analysis of the psychological content of the stages of childhood and ripening of the individual and proposed his own age-periodization of the child's development (Balay, 1995) (Table 1).

Periods of mental development of a child by S. Balay.

\begin{tabular}{|c|c|c|c|c|}
\hline Period & Phase & Age & \multicolumn{2}{|l|}{ Main features } \\
\hline \multicolumn{2}{|l|}{ The baby's age } & $\begin{array}{l}\text { The first year of } \\
\text { life }\end{array}$ & \multicolumn{2}{|c|}{$\begin{array}{l}\text { Owning a body (the child learns to sit, crawl and stand). } \\
\text { Sensory-moving interest. Hand-held fun. }\end{array}$} \\
\hline \multirow[t]{3}{*}{$\begin{array}{l}\text { Childhood, from } 1 \\
\text { to } 12-13 \text { years old }\end{array}$} & First childhood & $\begin{array}{l}\text { By the end of } \\
3^{\text {rd }} \text { year of life }\end{array}$ & Egocentrism & $\begin{array}{l}\text { Acquisition of language. } \\
\text { Imaginary games. Beginning the } \\
\text { ages of curiosity. }\end{array}$ \\
\hline & Second childhood & $\begin{array}{l}\text { By the } 7^{\text {th }} \text { year } \\
\text { of life }\end{array}$ & $\begin{array}{l}\text { Magic thinking, } \\
\text { interest in fairy tales }\end{array}$ & $\begin{array}{l}\text { Improvement of speech, } \\
\text { constructive games, curiosity. }\end{array}$ \\
\hline & Third childhood & $\begin{array}{l}\text { Up to the } 13-14 \\
\text { years of life }\end{array}$ & Realism & $\begin{array}{l}\text { Natural and technical interests. } \\
\text { Collecting. } \\
\text { Heroization. }\end{array}$ \\
\hline \multirow[t]{3}{*}{ Age of maturation } & Pre-flowering & $\begin{array}{l}\text { About } 13-14 \\
\text { years of life }\end{array}$ & \multicolumn{2}{|c|}{$\begin{array}{l}\text { Manifestations of disobedience, depression and } \\
\text { impudence. Psychological differentiation by sexual } \\
\text { characteristics. }\end{array}$} \\
\hline & $\begin{array}{l}\text { Flourishing (puberty } \\
\text { phase) }\end{array}$ & $\begin{array}{l}\text { By } 17^{\text {th }} \text { year of } \\
\text { life }\end{array}$ & \multicolumn{2}{|c|}{$\begin{array}{l}\text { Sexual maturity. Adoration. Sensitive enzyme. } \\
\text { Romanticism. A sense of love. Dreamy fantasies. }\end{array}$} \\
\hline & $\begin{array}{l}\text { Juvenile } \\
\text { (adolescence) }\end{array}$ & $\begin{array}{l}\text { By } 20-24 \text { year } \\
\text { of life }\end{array}$ & \multicolumn{2}{|c|}{$\begin{array}{l}\text { Youth idealism. Socialization of personality. Formation } \\
\text { of aesthetic feelings. }\end{array}$} \\
\hline
\end{tabular}

Describing the peculiarities of childhood, S. Balay distinguished the plasticity of mental processes, making the adult have significant opportunities for managing the development of the child; specific figurative and spontaneous character of the child's psyche, which require an adult to adhere to certain rules of pedagogical interaction. The scientist emphasized that at an early age the child especially needs a confidential attitude towards himself, the approval of his behavior from the part of the adult and the creation of a situation of success.

Taking into account the age and individual psychological characteristics, the scientist made a psychological justification of the methods of influencing the child and controlling his behavior. So, S. Balay promoted pedagogical methods aimed at encouraging the child (demand, instruction, reminder, advice, praise), and was extremely negative in applying in the process of upbringing a punishment, believing that it causes children a sense of shame, fear, humiliation.

\section{Discussion}

One of the prominent places in the scientific searches of S. Balay is the problem of the personality of the teacher (educator), which was quite actual and controversial at the time. At the beginning of the twentieth century under the influence of progressive socio-pedagogical ideas in Europe there was the development of education, changing views on the school of that time. The teacher was considered not only as an observer and researcher in the development of the child's personality, but above all - as the leader of this process. S. Balay considered the pedagogical process as covering the «external» (direct effect of the teacher on the child) and «internal» (selfdevelopment) aspects. Proceeding from the fact that the person of the teacher-educator is of great 
importance for the success of the pedagogical interaction, S. Balay paid considerable attention to the study of what traits and skills should have a teacher.

In the psychological and pedagogical literature of that period, numerous attempts were made to study the traits of a teacher, constructing his professionograms. The basis for comparison was the features recognized as characteristic and desirable for a good educator; while the lists of desirable rice were often so large and disorderly that it was difficult to orientate among them. Analyzing contemporary methods and attempts to classify the psychological features of a teachereducator (E. Spranger, E. Kretschmer), S. Balay stressed on the necessity to determine the correlation between these qualities and the results of educational activities. Following the Polish researchers (M. Kreutz, M. Gzhegozhevska, C. Schumann) who introduced the term «personalit» in relation to the teacher-educator, S. Balay interpreted the teacher-educator as a person with a peculiar, more or less homogeneous structure and considered the artificial idea of an «integral teacher» with a long list of characteristic features.

Considering the personality of the teacher as an integral structure of interconnected properties, S. Balay distinguished in this structure as innate elements of pedagogical abilities and acquired. The scientist referred to the important qualities of the teacher intellect, moral and volitional qualities, developed skills of self-education, the desire to improve the level of professional training. S. Balay attributed to special teaching abilities a scientific preparation (degree of knowledge of the subject, its methodology, general didactic principles, child psychology); personal teacher talent (pedagogical talent, creativity); constant work of the teacher over their development and improvement. In addition, he stressed the importance of:

- love of educator to pupils, which, according to the scientist, is an integral part of pedagogical abilities;

- understanding of the child;

- desire and ability to work closely with young people, a special setting for systematic classes with children, direct communication;

- congeniality (the relationship between the structures of the teacher and the pupil) and a certain infantilism of the educator, which contributes to a special kind of spiritual affinity with the children;
- patience, which is especially important in working with underdeveloped and morally neglected children;

- tactfulness - the ability to communicate with children in such a way as not to cause conflicts, but, on the contrary, to positively influence the child (Балей, 2009).

S. Balay believed that the communication of the teacher with the child is an essential condition of education. In order for communication to have the necessary impact on the child, the teacher should take a pedagogical position - respond to different forms of behavior of the child, evaluating them, instilling certain standards to the pupil. The scientist described the phenomenon of adoration, which in the modern sense would mean emotional enthusiasm, is closely related to the idealization of the object and the identification of the subject with him. In the relationship of attachment, the scientist saw the wide possibilities for the influence of the eldest on the junior, as the children's perception of different judgments, emotional guides and certain forms of behavior becomes the starting point for conscious efforts to form themselves on the example of the elders.

Justified by S. Balay psychology of education is a holistic system of views, based on the principles of humanism and taking into account the age and individual characteristics of children in the pedagogical process. A significant number of provisions formulated by scientists have not lost relevance today. In particular, by substantiating the concept of the new school as an important developmental environment for the child's personality, S. Balay believed that the new school should be based on the principles of cooperation between educators and students; the spirit of pedagogical love, tolerance, tact, and not the ancient principle of fear and obedience should prevail. Undoubtedly, these provisions are relevant in the context of modern educational reforms.

The psycho-pedagogical ideas of S. Balay were of great importance for the development of psychological science, the training of specialists and the promotion of psychological knowledge. S. Balay developed and popularized new progressive psychological trends and methods, in particular the method of psychoanalysis, which was used by him in the studies of the works of T. Shevchenko and Yu. Slovatskii, as well as critically understood and supplemented by the scholars regarding the 
psychic peculiarities of the development of the child and the stage of this process. For the history of domestic psychology, it is important that S. Balay became the author of the first textbook on psychology in Ukrainian «Essay of Psychology» (1922) (Balay, 1922).

Significant importance of S. Balay's creativity for the development of the theory and practice of pedagogical psychology is conditioned by the fact that the scientist scientifically substantiated his own consistent conception of the education of the child's personality, which is marked by a systematic vision of the child's development process, an understanding of the pedagogical process as a subject-subject interaction, proclaims love to the child as the basis of education, recognizes the leading role of moral and value education, the idea of integrity when considering the individual. According to the scientist, the future of the educational system lies in the direction of personally determined individualized learning.

The provisions of S. Balay correspond with the ideas of humanistic psychology, the subjectsubject approach in pedagogy and psychology, the child's self-activity as a subject of education and upbringing, and developed in the scientific concepts of Ukrainian and Polish psychologists (O. Vlasova (Власова, 2005), M. Żebrowska (Żebrowska, 1952), etc.). The belief of the scientist in the necessity of organizing the educational process on the principles of organic synthesis of sciences with the broad involvement of psychological developments, focusing on the student's and teacher's personal development, promoting the optimal development of individual qualities, abilities, inclinations of the child, taking into account the unity of the somatic and mental development of the individual in the process of pedagogical interaction correspond to modern educational tasks.

\section{Conclusions}

The educational psychology of S. Balay is an integral system of views, which throws out studying the patterns of pedagogical interaction and the formation of the personality of the child for the purposeful implementation of the pedagogical process, taking into account its age and individual characteristics, especially the mental activity of man in the development process. The systematic vector of the educational psychology of S. Balay is its humanistic orientation on the education and upbringing of the child's personality.

The subject of the educational psychology of $\mathrm{S}$. Balay, in essence, is pedagogical interaction as «educational processes», as well as their subjects - the pupil and the educator. Pedagogical interaction is an important object of psychological and pedagogical research of the scientist, specifying in the justification of the principles of this interaction, methodical tools, requirements for the teacher's personality and his competencies.

Significant importance of S. Balay's creativity for the development of pedagogical psychology is determined by the justification of the consistent system conception of education, which is marked by the understanding of the pedagogical process as a subject-subject interaction, proclaims love for the child as the basis of this interaction. It is substantiated that the ideas expressed by S. Balay have far ahead of their time: these provisions, comprehension, confirmed and developed by modern scholars, are useful for solving the theoretical and practical problems that today are facing by psychological and pedagogical science.

Conflict of interest. We state that there is no conflict of scientific interests.

\section{References}

Baley S. (1922). Narys psihologiyi: novitnya biblioteka [Sketch of psychology: the newest library ]. Lviv-Kiyiv: Novi shlyahy. [in Ukrainian]

Baley S. (1995). Psihologichna opika v shkoli [Psychological care at school]. Vybrani pratsi z sotsialnoyi i pedagogichnoyi psyhologiyi [per. z pol.]. T.: Ternop. eksperim. In-t ped. osvity. [in Ukrainian]

Baley S. (2009). Zibrannya prats: u 5 t., 2 kn. / Stepan Baley; [uklad., vidp. i nauk. red. M. Vernikov]. L.: Lvivska politehnika. T. 2. 511 s. [in Ukrainian]

Baley S. (1938). Psychologia wychowawcza w zarysie [wyd. 3-e] [Educational psychology in the sketch]. Warszawa: PWN. [in Polish]

Baley S. (1983). Encyklopedia Powszechna. [wyd. 2-e] [Universal Encyclopedia]. Warszawa: PWN. [in Polish]

Craighead E.W. (2002). Between Two World Wars (1918-1939). The Corsini Encyclopedia of Psychology and Behavioral Science, 3, 1218. [in English]

Goncharenko O.A. (2011). Filosofskopedagogichna kontseptsiya S.Baleya $u$ 
suchasnomu osvitnomu prostori [Philosophical and pedagogical concept of S.Balay in the modern educational space]: $\mathrm{PhD}$ thesis. Kiyv, $177 \mathrm{~s}$. [in Ukrainian]

Jadczak R. (1997). Stefan Baley. Mistrz i jego uczniowie [Master and his student]. Warszawa, 68-70. [in Polish]

Kosnarewicz E. (1992). Stefan Baley. Stownik psychologów polskich [Glossary of polish psychologists]. Poznań, 19-21. [in Polish]

Petrovskiy A.V. (1973). Nekotoryie aktualnyie problemy razrabotki istorii psihologii [Some topical problems in the development of the history of psychology]. Problemy teorii $i$ istorii razvitiya psihologii: materialy simpoziuma. Moscow: APN SSSR. NII defektologii, 111-123. [in Russian]

Romenets V.A. (1998). Istoriya psihologii XX stolittya [The history of psychology of the $X X$ century]. K.: Libid. [in Ukrainian]

Rybalka V.V. (2009). Teoriya osobystosti u vitchiznyaniy psyhologii ta pedagogitsi [Personality theory in the national psychology and pedagogy]: navch. posib. Odesa: Bukaev V.V., 575 s. [in Ukrainian]

Twardowski K. (1997). O psychologii, jej przedmiocie, zadaniach, metodzie, stosunku do innych nauk i jej rozwoje [About psychology, its subject, tasks, method, relation to other sciences and its development]. Psychologia w szkole lwowsko-warszawskiej. Warszawa, 142-183. [in Polish]

Vasyanovich G.P. (2005). Kategoriya dobra i zla v etyko-psihologichnyh poglyadah Stepana Baleya [The category of good and evil in the ethical and psychological views of Stepan Balay]. Pedagogika i psihologiya profesiynoyi osvity, 4, 197-203. [in Ukrainian]

Vernikov M.M. (2002). Zhittya i naukova diyalnist akademika Stepana Baleya [Life and scientific activity of academician Stepan Balay]: [peredm. do zibr. pr.]. Zibr. pr.: u 5 t., 2 kn. / M. M. Vernikov. Lviv - Odesa, T. 1, 19-79. [in Ukrainian]

Vlasova O. (2005). Psihologiya sotsialnyh zdibnostey: struktura, dinamika, chynnyky rozvytku [Psychology of social abilities: structure, dynamics, factors of development]. Kiyiv, Vydavnycho-poligrafIchniy tsentr «Kiyivskiy universitet». [in Ukrainian]

Yaroshevskiy M.G. (1996). Istoriya psihologii [The history of psychology]. Moscow: Myisl. [in Ukrainian]

Yatyschuk A. (2012). Naukova diyalnist S. Baleya u sferi psihologii vyhovannya [S. Balay's scientific activity in the field of educational psychology]. Materialy mezhdunar. nauch.prakt. konf. «Perspektywy rozwoju nauki we wspolczesnym swiecie» (Krakow, 29-31 marzca 2012). Krakow: Wydawca Sp.z.o.o. «Diamond trading tour», 23-29. [in Ukrainian]

Żebrowska M. (1952). Stefan Baley (1885-1952) [Stefan Balay (1885-1952)]. Roczniki TNW, 45, 89-92. [in Polish]

Ziemnowicz M. (1953). Stefan Baley na tle współczesnej epoki [Stefan Balay against the background of the modern era]. Roczniki Humanistyczne. T. IV, 141-167. [in Polish] 